\title{
CONFIGURATION OF THE DRAINAGE SYSTEM OF MIDTDALSBREEN, NORWAY, AS INDICATED BY DYE-TRACING EXPERIMENTS
}

\author{
By IAN C. Willis, Martin J. Sharp, and KeIth S. Richards \\ (Department of Geography, University of Cambridge, Cambridge CB2 3EN, England)
}

\begin{abstract}
During the summers of 1987 and 1988, 15 dye-tracer tests from a total of eight injection points were conducted in the ablation area of Midtdalsbreen, a northern outlet of Hardangerjøkulen, southern Norway. The spatial and temporal patterns of water discharge, shapes of the dye-return curves, through-flow velocities, dye-recovery rates, dispersivities, and velocity/discharge relationships suggest the existence of distinct catchments beneath the eastern and western halves of the glacier which are characterized by different types of drainage sytem. Experiments on the eastern side were associated with high melt-water discharges and produced short-lived and highly peaked dye-return curves, fast through-flow velocities, high dye-recovery rates, low dispersivity values which decreased through the melt season, and a velocity/discharge relationship with an exponent of 1.0. Experiments on the western side were associated with low melt-water discharges and produced flat, extended dye-return curves which of ten displayed secondary peaks, slow through-flow velocities, low dye-recovery rates, high dispersivity values which increased during the melt season, and a velocity/discharge relationship with an exponent of 0.6. Comparison of observed through-flow velocities with values calculated theoretically using various hypothetical drainage-system structures suggests that water flows in a major sinuous conduit beneath the eastern half of the glacier and in a system of linked cavities beneath the western half. A model for the seasonal evolution of the whole drainage network is postulated which has important implications for temporal variations in subglacial water pressures and glacier-sliding velocity.
\end{abstract}

\section{INTRODUCTION}

Water flowing beneath glaciers is widely believed to play an important role in controlling their sliding velocity (Iken, 1978, 1981). Although the precise mechanisms involved are poorly understood, it is generally accepted that the subglacial water pressure is an important variable, acting through its influence on basal friction (Iken, 1981; Bindschadler, 1983). This water pressure is largely a function of the structure of the subglacial drainage system, the hydraulic geometry of the individual drainage passageways, and the melt-water discharge.

Several models have been developed to describe subglacial water flow, and all appear to have some support from field evidence. Flow has been postulated to occur in large channels cut into basal ice or bedrock (Röthlisberger, 1972; Shreve, 1972; Nye, 1976; Spring and Hutter, 1981), in a thin water film of variable thickness (Weertman, 1972; Vivian, 1980), through a permeable subglacial sediment layer (Boulton and Jones, 1979; Shoemaker, 1986; Boulton and Hindmarsh, 1987), or through a system of linked cavities developed on the down-stream side of bedrock obstacles (Lliboutry, 1968; Walder, 1986; Kamb, 1987). Different drainage-system structures are characterized by contrasting relationships between melt-water discharge and subglacial water pressure, such that for tunnel-dominated drainage systems there is an inverse relationship between these two variables (Röthlisberger, 1972), while for linked-cavity systems the relationship is positive (Walder, 1986; Kamb, 1987). Hence, a given melt-water discharge can produce very different water pressures depending upon the type of subglacial drainage system.

Understanding of the structure of subglacial drainage systems is therefore critical to any analysis of glacier flow (Raymond and Harrison, 1988). This can best be achieved by either the study of recently deglaciated terrains (Walder and Hallet, 1979; Hallet and Anderson, 1980; Sharp and others, 1989) or by modelling the dispersion of tracers within the glacier-drainage system (Seaberg and others, 1988; Brugman, unpublished). It is this latter approach which we adopt in this study. As part of a broader investigation into the links between the hydrology and flow of Midtdalsbreen, southern Norway, a series of dye-injection tests was carried out during the summers of 1987 and 1988. These experiments were designed to determine the nature of the glacier's subglacial drainage system, to establish the manner and extent to which it varies in character within and between melt seasons, and to determine the implications of this behaviour for subglacial water pressures and rates of glacier sliding.

\section{THE STUDY SITE}

Midtdalsbreen is a $9 \mathrm{~km}^{2}$ temperate outlet glacier on the northern margin of Hardangerjøkulen near Finse in southern Norway (Fig. 1). The glacier extends from 1400 to $1830 \mathrm{~m}$ a.s.l., is underlain by granitic gneiss and phyllite bedrock, and is drained by three melt-water steams. The largest of these, T1, emerges from the glacier snout close to its eastern margin, flows over a $70 \mathrm{~m}$ high rock step beneath an area of dead ice, and re-emerges to flow across a small outwash fan in a series of distributaries (Fig. 1). The smallest stream, T2, initially emerges from beneath the central part of the glacier snout and merges with two small streams which drain two ice-marginal lakes before flowing over the dead ice-covered rock step and joining T1 and T3 at its base (Fig. 1). The third stream, T3, emerges near the western margin of the glacier snout, flows over the rock step beneath the dead ice, and then forms a steep braided stream which merges first with $\mathrm{T} 2$ and then with $\mathrm{T} 1$ (Fig. 1).

\section{MEASUREMENT PROCEDURE}

\section{Dye tracing}

During the summers of 1987 and 1988, 15 dyeinjection tests were conducted in the ablation area of Midtdalsbreen. A total of eight injection points was used (Fig. 1). In 1987, after a winter of heavy snowfall, the air temperature did not rise above $0^{\circ} \mathrm{C}$ until 22 April and 


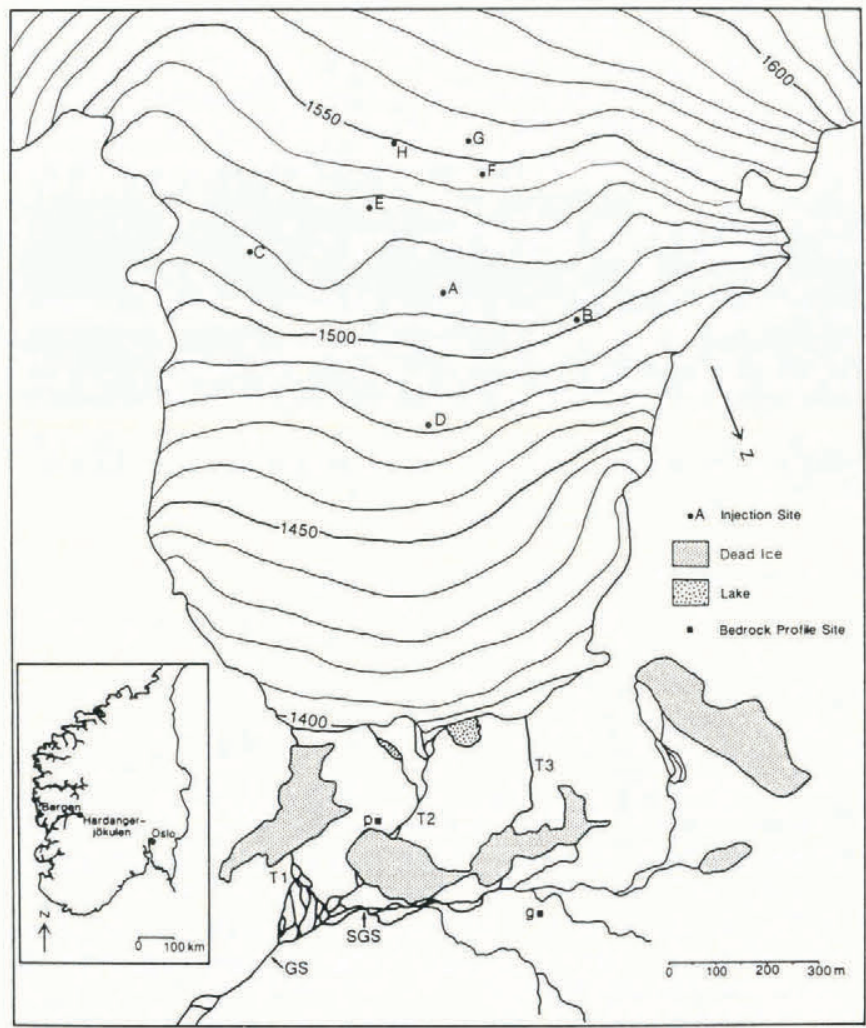

Fig. 1. Map of Midtdalsbreen showing injection sites $(A-H)$. pro-glacial tributary streams (T1, T2, and T3), gauging station (GS), subsidiary gauging station (SGS), and the sites of the granite $(g)$ and phyllite $(p)$ bedrock profiles. The surface contours (in $m$ ) are from a map based on 1961 aerial photographs.

remained unusually cool during May and June. As a result, there was very little supraglacial drainage and the following injection procedure was used: a known quantity of rhodamine B powder was diluted in 301 of water and poured into a crevasse down which running water could be seen or heard. In 1988, following a winter of light snowfall, the air temperature first exceeded $0^{\circ} \mathrm{C}$ on 1 April and the number of positive degree-days during May and June was $108 \%$ greater than in 1987. Because of this, there was much surface melt water, so a known quantity of rhodamine B powder was poured into a supraglacial stream as it disappeared down a moulin or crevasse. Thus, the majority of the dye immediately entered the englacial drainage system in each test. Details of the dye-injection tests are presented in Table I.

\section{TABLE I. DETAILS OF DYE-EXPERIMENT INJECTION}

\begin{tabular}{|c|c|c|c|c|c|}
\hline \multirow[t]{2}{*}{ Test } & Date & Time & $\begin{array}{l}\text { Input } \\
\text { point }\end{array}$ & $\begin{array}{c}\text { Travel } \\
\text { distance }\end{array}$ & $\begin{array}{l}\text { Weight o } \\
\text { dye inpu }\end{array}$ \\
\hline & & $\mathrm{h}$ & & $\mathrm{m}$ & $\mathrm{g}$ \\
\hline $87-1$ & $11 \mathrm{Jul}$ & 15.00 & A & 1360 & 140 \\
\hline $87-2$ & $15 \mathrm{Jul}$ & 11.00 & A & 1360 & 200 \\
\hline $87-3$ & $20 \mathrm{Jul}$ & 15.00 & B & 1400 & 190 \\
\hline $87-4$ & $23 \mathrm{Jul}$ & 14.45 & $\mathrm{C}$ & 1400 & 200 \\
\hline $87-5$ & $27 \mathrm{Jul}$ & 15.00 & C & 1400 & 200 \\
\hline $87-6$ & 3 Aug & 16.00 & A & 1360 & 200 \\
\hline $87-7$ & 15 Aug & 13.00 & D & 1100 & 200 \\
\hline $87-8$ & 27 Aug & 12.45 & E & 1500 & 200 \\
\hline $88-1$ & 29 Jun & 16.00 & $\mathrm{~F}$ & 1610 & 300 \\
\hline $88-2$ & $8 \mathrm{Jul}$ & 16.00 & G & 1650 & 300 \\
\hline $88-3$ & $13 \mathrm{Jul}$ & 12.00 & $\mathrm{H}$ & 1640 & 300 \\
\hline $88-4$ & $18 \mathrm{Jul}$ & 12.00 & $\mathrm{~F}$ & 1610 & 200 \\
\hline $88-5$ & $23 \mathrm{Jul}$ & 14.00 & $\mathrm{H}$ & 1640 & 300 \\
\hline $88-6$ & $27 \mathrm{Jul}$ & 12.00 & $\mathrm{~F}$ & 1610 & 300 \\
\hline & $28 \mathrm{Jul}$ & 16.00 & G & 1650 & 300 \\
\hline
\end{tabular}

At a stable cross-section on the melt-water stream $600 \mathrm{~m}$ from the glacier snout and just down-stream of the confluence of the three tributaries, water samples were taken with an automatic liquid sampler at intervals of between 5 and $30 \mathrm{~min}$ from the time of dye injection until the dye concentration had peaked and dropped below $0.5 \mathrm{ppb}$. Thereafter, the sampling interval was increased to $1 \mathrm{~h}$ and sampling was continued for at least $24 \mathrm{~h}$ after the dye concentration had last fallen below the level of detectability. Once dye was detected, water samples were taken manually from each of the three tributary streams to determine at which point the dye was leaving the glacier. Tracer concentrations in outflowing melt waters were determined with a battery-powered Turner Designs 10-005 fluorometer within $9 \mathrm{~h}$ of sample collection. The fluorometer was calibrated with standard concentrations before and after each field season, and dye concentrations could be detected down to $0.1 \mathrm{ppb}$ (S.E. $\pm 4 \%$ ).

\section{Discharge determination}

A gauging station (GS) was established at the section of the main channel where water samples were collected. Water stage was logged every hour throughout each field season using a Druck PDCR 830 pressure transducer and a Campbell Scientific $21 \mathrm{X}$ data logger. The stream crosssection was gauged 42 times in 1987 and 14 times in 1988 by a conventional mean-section current-metering procedure. To ensure that there was no change in the channel geometry, the section was levelled 42 times throughout the summer of 1987. Given that about $0.1 \mathrm{~m}$ of between-survey variability is attributable to the calibre of the bed material, the results indicate that there was no significant change in the geometry of the cross-section. An unusually high discharge associated with a storm on 21 August 1987 displaced the pressure transducer, so two separate rating curves had to be established for 1987 (pre- and post-flood). These curves have standard errors of \pm 5 and $\pm 7 \%$, respectively, and are shown in Figure 2 together with the stage-discharge curve for 1988 (S.E. $\pm 5 \%$ ). These curves were used to calculate hourly values of melt-water discharge from the pressure-transducer readings throughout the two ablation seasons.

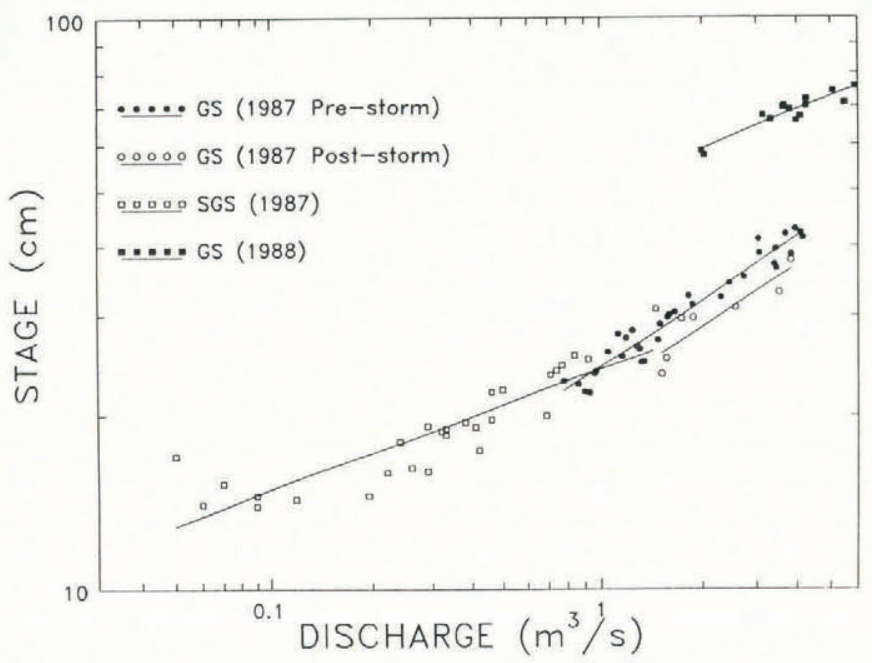

Fig. 2. Stage-discharge curves for the gauging station (GS) in 1987 and 1988 and for the subsidiary gauging station (SGS) in 1987.

Between 20 July and 29 August 1987, 26 measurements of stage and discharge were made at a subsidiary gauging station (SGS) up-stream of the confluence of T3 with T1 and T2 (Fig. 1) in order to assess the relative magnitudes of discharges in the two streams. These measurements were taken at different times of day and under differing meteorological conditions. The stage-discharge curve for this section has a standard error of $\pm 10 \%$ (Fig. 2). Discharges at SGS ranged from 3 to $29 \%$ of the contemporaneous discharges at GS, although 18 of the 26 values lay between 13 and $25 \%$. The average for all 26 readings was $17 \%$. 
Except for three small pro-glacial nival streams, all the water flowing past SGS originates beneath the western glacier margin, so for the purposes of this study discharges in $\mathrm{T} 3$ and $\mathrm{T} 1 / \mathrm{T} 2$ were assumed to be 17 and $83 \%$, respectively, of those at GS.

\section{RESULTS OF THE DYE-TRACING EXPERIMENTS}

Figure 3 shows plots of stream discharge, dye concentration, and the cumulative percentage of dye recovered against time for some of the tests. There are several general points to be made about the experimental results.

\section{Lateral division of the drainage system}

Table II lists the tributary stream(s) in which the dye emerged for each experiment. In tests 87-4 and 87-5, when dye was injected into an east-trending crevasse (site $\mathrm{C}$ ), the dye re-appeared in $\mathrm{Tl}$. For experiment 87-3, when the injection site was a west-trending crevasse (site B), the dye emerged in $\mathrm{T} 3$. In all other tests, dye was poured into central crevasses and moulins, and exited in $\mathrm{T} 1$ from sites $E$ and $H$, in $T 3$ from sites $A$ and $F$, and in both $T 2$ and T3 for test 87-7 from site D. For tests 88-2 and 88-7 from site G, no dye was detected at GS, although water sampling continued for $60 \mathrm{~h}$ after each dye injection. It therefore appears that $\mathrm{Tl}$ drains the eastern half of the glacier, while T3 drains the western half.

\section{Variation in through-flow velocities}

For each experiment, including the multiple peaks of tests, $87-2,87-6,87-7$, and $88-4$, through-flow velocities, $u$, were calculated (Table II) by dividing the straight-line distance from the injection site to GS, $x$, by the time from dye injection to peak concentration, $t_{\mathrm{m}}$. To allow calculation of true intraglacial velocities, an attempt was made to assess the time taken for dye to travel from the glacier snout to GS. Pro-glacial travel distances are $450 \mathrm{~m}$ for $\mathrm{T} 1$ and $750 \mathrm{~m}$ for $\mathrm{T} 3$, and average cross-section pro-glacial velocities (from the current-meter measurements taken during discharge determination at GS and SGS, respectively) are $0.6 \mathrm{~m} \mathrm{~s}^{-1}$ in $\mathrm{T} 1$ and $0.4 \mathrm{~m} \mathrm{~s}^{-1}$ in $\mathrm{T} 3$. These figures suggest pro-glacial travel times of about $13 \mathrm{~min}$ in $\mathrm{Tl}$ and $31 \mathrm{~min}$ in $\mathrm{T} 3$.
Recalculation of velocities using the intraglacial travel time and the straight-line distance from the injection point to the point at which the relevant stream exited from the glacier snout gave intraglacial velocities which were the same (to two decimal places) as those originally calculated.

For tests 88-2 and 88-7 from site $G$, when no dye was detected at GS, the dye either emerged after monitoring at GS had finished (in which case through-flow velocities were $<0.008 \mathrm{~m} \mathrm{~s}^{-1}$ ) or passed into temporary storage (e.g. in subglacial sediments and/or one or more sub- or englacial water bodies) and was released so slowly that it passed GS at undetectable concentrations. Through-flow velocities from injection sites B, C, and $\mathrm{H}$ ranged between 0.086 and $0.228 \mathrm{~m} \mathrm{~s}^{-1}$ and, except for test $87-3$, were all associated with dye return in T1. These velocities lie within the range found in experiments on other glaciers where flow was assumed to occur via major conduits (Stenborg, 1969; Krimmel and others, 1973; Behrens and others, 1975; Lang and others, 1981; Collins, 1982; Burkimsher, 1983; Seaberg and others, 1988). Velocities from dye-input points $A, D, E$, and $F$ were generally an order of magnitude lower $\left(0.010-0.070 \mathrm{~m} \mathrm{~s}^{-1}\right)$ and, with the exception of test 87-8, were associated with dye return in T3. These velocities are comparable with those reported by other workers for situations where flow was inferred to occur via a more distributed hydrological system (Theakstone and Knudsen, 1981; Iken and Bindschadler, 1986; Brugman, unpublished). This suggests that $\mathrm{T} 1$ and $\mathrm{T} 3$ may be fed by different types of drainage system.

\section{Shape of the dye-concentration time curves}

In general, those dye-return curves associated with relatively fast through-flow velocities showed peaks of short duration and asymmetrical shape, in which a sharp rise to peak was followed by an initial sharp fall and then by a more gentle decline (Fig. 3b and c). Dye-return curves giving slower velocities were generally more erratic and broader, indicating that the dye became more dispersed as it travelled through the glacier. A characteristic feature of these curves is the occurrence of multiple peaks of dye concentration which were separated by as much as $30 \mathrm{~h}$ (Fig. 3a and d).

Multiple peaks separated by only a few hours were recorded during tests on Peyto Glacier (Collins, 1982),
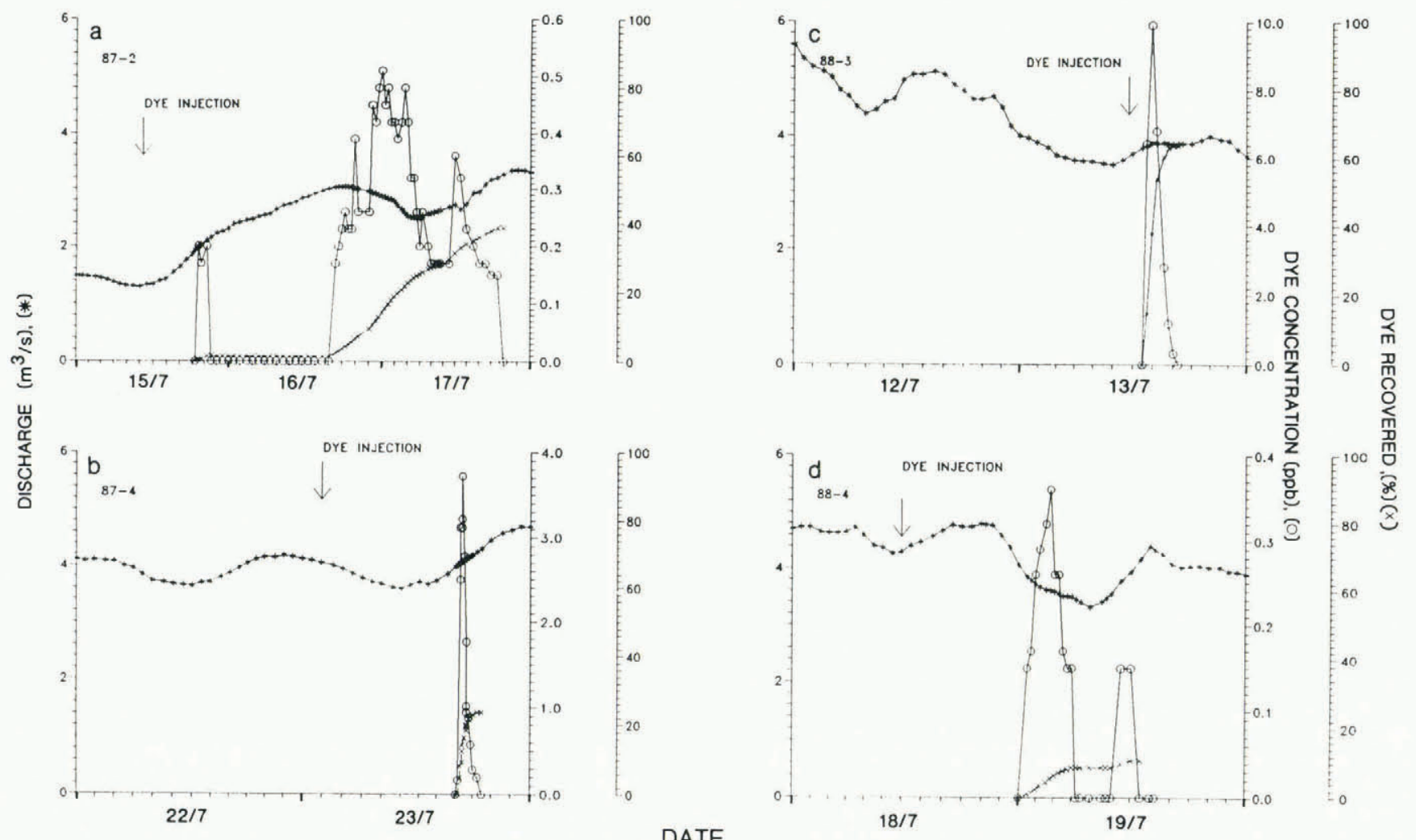

DATE

Fig. 3. Stream discharge, dye concentration, and cumulative percentage of dye recovered at the gauging station against time for tests (a) 87-2, (b) 87-4, (c) 88-3, and (d) 88-4. 


\begin{tabular}{|c|c|c|c|c|c|c|c|}
\hline \multirow[t]{3}{*}{ Test } & $\begin{array}{c}\text { Outflow } \\
\text { stream }\end{array}$ & Recovery & $\begin{array}{l}\text { Tributary } \\
\text { discharge }\end{array}$ & $\begin{array}{c}\text { Through-flow } \\
\text { velocity }\end{array}$ & $\begin{array}{l}\text { Dispersion } \\
\text { coefficient }\end{array}$ & $\begin{array}{l}\text { Best* } \\
\text { model }\end{array}$ & Dispersivit \\
\hline & & & $Q_{\mathrm{T}}$ & $u$ & $D$ & & $\alpha$ \\
\hline & & $\%$ & $\mathrm{~m}^{3} \mathrm{~s}^{-1}$ & $\mathrm{~m} \mathrm{~s}^{-1}$ & $\mathrm{~m}^{2} \mathrm{~s}^{-1}$ & & $\mathrm{~m}$ \\
\hline $87-1$ & T3 & 11 & 0.21 & 0.027 & 0.02 & $\mathrm{DD}$ & 0.7 \\
\hline $87-2 A$ & T3 & & 0.27 & 0.047 & 0.23 & DD & 4.9 \\
\hline $87-2 B$ & T3 & & 0.40 & 0.010 & 0.12 & DD & 12.0 \\
\hline $87-2 \mathrm{C}$ & T3 & 39 & 0.43 & 0.007 & 0.01 & DD & 1.4 \\
\hline $87-3$ & T3 & 25 & 0.67 & 0.086 & 1.44 & DDSR & 16.7 \\
\hline $87-4$ & $\mathrm{~T} 1$ & 24 & 3.31 & 0.181 & 1.81 & DD & 10.0 \\
\hline $87-5$ & $\mathrm{Tl}$ & 95 & 1.57 & 0.122 & 1.55 & DDSR & 12.7 \\
\hline $87-6 \mathrm{~A}$ & T3 & & 0.34 & 0.050 & 2.09 & DDSR & 41.8 \\
\hline $87-6 B$ & T3 & & 0.34 & 0.020 & 0.09 & DD & 4.5 \\
\hline $87-6 C$ & T3 & 53 & 0.33 & 0.010 & 0.07 & DD & 7.0 \\
\hline $87-7 \mathrm{~A}$ & $\mathrm{~T} 2 / \mathrm{T} 3$ & & 0.30 & 0.024 & 0.11 & DD & 4.6 \\
\hline $87-7 B$ & $\mathrm{~T} 2 / \mathrm{T} 3$ & 26 & 0.28 & 0.011 & 0.08 & DD & 7.3 \\
\hline $87-8$ & $\mathrm{~T} 1$ & 18 & 2.25 & 0.070 & 1.33 & DD & 19.0 \\
\hline $\begin{array}{l}88-1 \\
88-2\end{array}$ & T3 & 52 & 0.91 & 0.037 & 0.87 & DDSR & 23.5 \\
\hline $88-3$ & $\mathrm{~T} 1$ & 64 & 3.17 & 0.228 & 16.20 & DD & 71.1 \\
\hline $88-4 \mathrm{~A}$ & T3 & & 0.69 & 0.029 & 0.24 & DD & 8.3 \\
\hline $88-4 B$ & T3 & 19 & 0.68 & 0.019 & 0.02 & DD & 1.1 \\
\hline $88-5$ & $\mathrm{~T} 1$ & 48 & 3.28 & 0.228 & 2.99 & DD & 13.1 \\
\hline $88-6$ & T3 & 10 & 0.53 & 0.056 & 0.64 & DDSR & 11.4 \\
\hline
\end{tabular}

* DD refers to a "diffusive-dispersion" model and DDSR to a joint "diffusive-dispersion" and "storageretardation" model.

Pasterzengletscher (Burkimsher, 1983), and Storglaciären (Seaberg and others, 1988). Such multiple peaks can be explained by assuming flow through more than one anabranch of a braided subglacial channel system, but such an explanation does not seem appropriate for the multiple peaks observed in our experiments $87-1,87-2,87-6,87-7$, and $88-4$ because of the long time interval between peaks. Some of the secondary peaks occurred at times of rising or maximum discharge and dye concentrations of ten dropped to zero at times of minimum discharge between peaks (Fig. 3a and d). Secondary peaks of this type were observed in some experiments undertaken on Findelengletscher (Iken and Bindschadler, 1986) and were attributed to either the tapping of subglacial conduits at times of high water pressure or the rinsing of subglacial cavities by surface-derived melt waters at times of high water input. They seem to require temporary storage of part of the dye cloud within the subglacial drainage system, a process which seems to be characteristic of the drainage system leading to T3 but not of that leading to T1.

\section{Dye recovery}

The weight of dye, $M$, which passed the gauging station during each experiment was calculated from

$$
M=\sum_{t=1}^{n} c Q_{\mathrm{GS}} \mathrm{d} t
$$

where $c$ is the dye concentration at time $t$ and $Q_{\mathrm{GS}}$ is the gauging-station discharge at time $t$. In Figure $3, M$ is expressed as a cumulative percentage of the weight of dye originally injected; the final percentage of dye recovered is given in Table II. Dye recovery was between 10 and $95 \%$ (although in most experiments $20-60 \%$ was recovered) and, in general, higher recovery rates were achieved in tests which produced faster through-flow velocities and dye return in $\mathrm{T} 1(49.8 \pm 31.3 \%)$ than in tests which resulted in dye return in T3 $(29.9 \pm 18.2 \%)$. Similar recovery rates of rhodamine $\mathrm{B}$ have been reported by other workers (Kilpatrick and others, 1967; Krimmel and others, 1973; Behrens and others, 1975). The errors associated with fluorometer calibration and discharge determination give a maximum dye-recovery error of less than $10 \%$ and, although rhodamine B suffers from large losses due to adsorption on to sediment (Smart and Laidlaw, 1977), this should not be a problem at the low sediment concentrations measured at GS $\left(<1000 \mathrm{mg} \mathrm{l}^{-1}\right)$ (Brugman, unpublished). Furthermore, since $95 \%$ of the dye was recovered in test $87-5$, it seems that another explanation is required to account for the low recovery rates in some tests. In test $87-5,15 \%$ of the dye arrived at GS at concentrations of less than $1 \mathrm{ppb}$, and therefore approached the level of minimum detectability. During this test the discharge in $\mathrm{T} 1$ was low $\left(<2 \mathrm{~m}^{3} \mathrm{~s}^{-1}\right)$, so it is possible that the dye-return curves for other experiments conducted at higher discharges possess long tails in which concentrations are too low to be detected by the fluorometer. This might reflect the slow release of dye adsorbed on to the walls of a crevasse or moulin during dye injection, or the storage and subsequent release of dye from subglacial locations. If the latter explanation is correct, dye-recovery rates provide further evidence that storagerelease processes are more characteristic of the $\mathrm{T} 3$ drainage system than of the T1 system.

\section{Summary}

The above discussion suggests that the catchments of $\mathrm{T} 1$ and $\mathrm{T} 3$ are spatially distinct and characterized by different types of drainage system. T1 derives its drainage from the eastern half of the glacier and is associated with high through-flow velocities, short, peaked dye-return curves, and relatively high dye-recovery rates, while T3 derives its drainage from the western part of the glacier and is associated with slow through-flow velocities, attenuated dye-return curves with multiple peaks, and low dye-recovery rates. Storage and subsequent release of dye seems to be characteristic of drainage to $T 3$, while dye draining to $\mathrm{Tl}$ seems to pass through the glacier as a single slug.

\section{BEHAVIOUR OF THE DRAINAGE SYSTEM}

\section{Variation of through-flow velocity with discharge}

Because the speed of water movement through a glacier will vary with the discharge in a manner which is dependent upon the geometry of the drainage sytem (Seaberg and others, 1988), we now investigate this relationship between velocity and discharge. As the discharge at GS varied during the passage of the dye cloud, discharge was 
defined as the mean discharge from the time of injection to the time of peak concentration. Since the discharge measured at GS exceeds the discharge in that part of the drainage network through which the dye cloud passed, discharge was taken as 17 or $83 \%$ of the discharge recorded at GS depending on whether the dye travelled to T3 or to T1. This is called tributary discharge $\left(Q_{\mathrm{T}}\right)$ in Table II. Figure 4 shows the through-flow velocities plotted against the inferred englacial/subglacial discharge for the 13 "successful" Midtdalsbreen tests and for the 13 tests carried out on Storglaciären by Seaberg and others (1988).

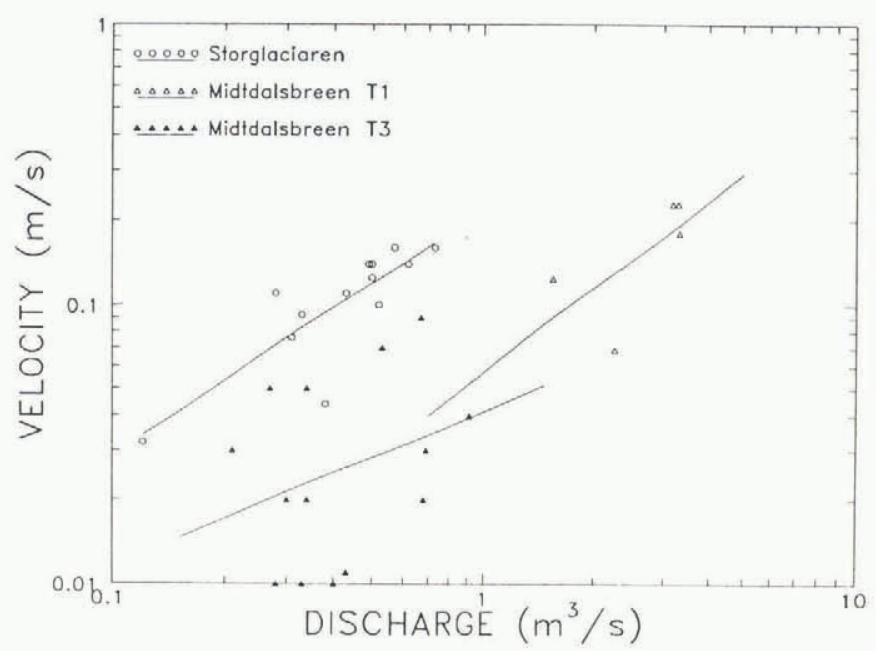

Fig. 4. Variation of flow velocity, $u$, with tributary-stream discharge, $\mathrm{Q}_{\mathrm{T}}$, for the 13 Storglaciären tests, five Midtdalsbreen $T 1$ tests, and eight Midtdalsbreen T3 tests.

The Midtdalsbreen data are divided into sub-sets for T1 and T3 since, from the previous discussion, it appears that these two streams are fed by two distinct types of drainage system. The regression relation for the T1 data conforms to the power function

$$
u_{\mathrm{T} 1}=0.06 Q_{\mathrm{T} 1}{ }^{1.0} \quad\left(r^{2}=0.44\right) .
$$

The multiplier 0.06 in this equation compares with that of 0.26 for the Storglaciären data, indicating that, for a given discharge, the velocity of water in $\mathrm{Tl}$ at Midtdalsbreen is four times less than in the stream which drains the southern margin of Storglaciären (Sydjokk). To account for this difference, the stream system feeding $\mathrm{Tl}$ must have a greater cross-sectional area and possibly also a greater sinuosity than that feeding Sydjokk. The exponent of the above relationship is 1.0 , the same as at Storglaciären. This suggests that the drainage system beneath the eastern side of Midtdalsbreen conforms to the model proposed by Seaberg and others (1988) of a system which accommodates higher discharges by increasing the hydraulic gradient driving the flow and by becoming less sinuous.

The velocity/discharge relationship for the T3 data is described by the equation

$$
u_{\mathrm{T} 3}=0.04 Q_{\mathrm{T} 3}{ }^{0.6} \quad\left(r^{2}=0.10\right) .
$$

Although this is a very weak relationship, which may in part be attributable to the influence of subglacial storage, the exponent of 0.6 would imply that a change in discharge through the drainage system beneath the western side of Midtdalsbreen is not solely accommodated by an adjustment in the through-flow velocity, but also by a change in cross-sectional area. Thus, the $\mathrm{T} 1$ and $\mathrm{T} 3$ drainage systems may show contrasting velocity-discharge relationships which indicate different processes of adjustment to varying discharge.

\section{Dispersion and theoretical dye-return curves}

Dispersion represents the temporal variation in the rate at which different "parcels" of dye from an original injection reach the pro-glacial stream (Brugman, unpublished, p. 158). It is a measure of the rate at which the dye-concentration peak broadens relative to the rate at which it is transferred through the glacier, and has units of $\mathrm{m}^{2} \mathrm{~s}^{-1}$. The arrival time of the dye peak at GS depends on the distance travelled and the average velocity of flow, but dispersion occurs because of the effects of diffusion and of storage and subsequent release of dye within the drainage system. Storage can occur in slow-moving or stagnant pools of water, back eddies, and water-filled cavities partially connected to major conduits or by adsorption on to sediment or rock surfaces (Brugman, unpublished, p. 222).

To determine the relative importance of diffusion and storage release as factors controlling the dispersion of dye, Brugman (unpublished) suggested two distinct theoretical models which can be used to describe dye-concentration curves: (i) a "diffusive-dispersion" model (DD), which produces an approximately symmetrical quasi-Gaussian curve of dye concentration through time, and (ii) a combination of a DD model with a "storage-retardation" model (DDSR) which produces a quasi-Gaussian curve during the rise of dye concentration followed by a quasi-exponental decline. The DD model best described the pattern of dye return for the experiment undertaken during the 1982-83 surge of Variegated Glacier, Alaska (Brugman, unpublished) and was used to model the results of the tests from the ablation zone of Storglaciären (Seaberg and others, 1988). The DDSR model best described the post-surge test of Variegated Glacier (Brugman, unpublished) and a test from the accumulation area of Storglaciären (Hooke and others, 1988). In this section, we conisder which model best describes the patterns of dye return for Midtdalsbreen.

Following Brugman (unpublished, equation (5.14)) and Seaberg and others (1988, equation (4)), a dispersion coefficient, $D$, was calculated for each of the observed dye-return curves:

$$
D=\frac{x^{2}\left(t_{\mathrm{m}}-t_{i}\right)^{2}}{4 t_{\mathrm{m}}{ }^{2} t_{i} \ln \left[2\left(t_{\mathrm{m}} / t_{i}\right)^{\frac{1}{2}}\right]} .
$$

Here $x$ is the total travel distance, $t_{\mathrm{m}}$ is the time to peak concentration, and $t_{i}$ represents $t_{1}$ and $t_{2}$, which are the times when the dye concentration reaches half its peak value on the rise to and decline from the peak, respectively. This equation is defined for $i=1$ and 2 , and is solved iteratively for $t_{\mathrm{m}}$ until a value is chosen such that the two equations are satisfied and $D$ is obtained. The dispersion coefficients for our tests range from $0.01 \mathrm{~m}^{2} \mathrm{~s}^{-1}$ for test $87-2 \mathrm{c}$ to $16.2 \mathrm{~m}^{2} \mathrm{~s}^{-1}$ for experiment $88-3$ (Table II). By comparison, Seaberg and others (1988) obtained values of between 0.8 and $2.7 \mathrm{~m}^{2} \mathrm{~s}^{-1}$ for their tests on Storglaciären, Brugman (unpublished) obtained a value of $30 \mathrm{~m}^{2} \mathrm{~s}^{-1}$ for her "surge-test" on Variegated Glacier, and Behrens and others (1975) obtained values between 0.45 and $1.1 \mathrm{~m}^{2} \mathrm{~s}^{-1}$ for their experiments on Hintereisferner.

Theoretical DD curves were calculated for each of the Midtdalsbreen experiments using the equation

$$
c(t)=\frac{u}{Q_{\mathrm{GS}}} \frac{V_{0}}{(4 \pi D t)^{\frac{1}{2}}} \exp -\frac{(x-u t)^{2}}{4 D t}
$$

(Brugman, unpublished, equations (5.5) and (5.10); Seaberg and others, 1988, equation (2)). Here, $c(t)$ is the dye concentration at time $t$ and $V_{0}$ is the volume of injected dye. The peak magnitudes of the theoretical curves were slightly different from those of the experimental curves because the discharge in the pro-glacial stream did not, as assumed, remain constant during a test. The peaks of the observed and theoretical curves were therefore brought into coincidence by adjusting the value of $Q_{\mathrm{GS}}$ in Equation (5). This necessitated multiplying $Q$ by a factor between 0.7 (test $87-8$ ) and 1.4 (test $87-5$ ). The DD model describes the rising limbs of all the tests reasonably accurately but only the curves of tests $87-1,87-2,87-4,87-7,87-8,88-3$, $88-4$, and $88-5$ (i.e. $80 \%$ of the tests which produced dye return in $\mathrm{T} 1$ and $50 \%$ of the tests which produced dye return in T3) can be modelled completely (Fig. 5). The secondary and tertiary peaks of dye concentration (labelled $B$ and $C$, respectively, in Figure 5) of tests $87-2,87-6$, $87-7$, and $88-4$ could also be modelled using this procedure but the other experimental curves exhibit long tails which 
Journal of Glaciology
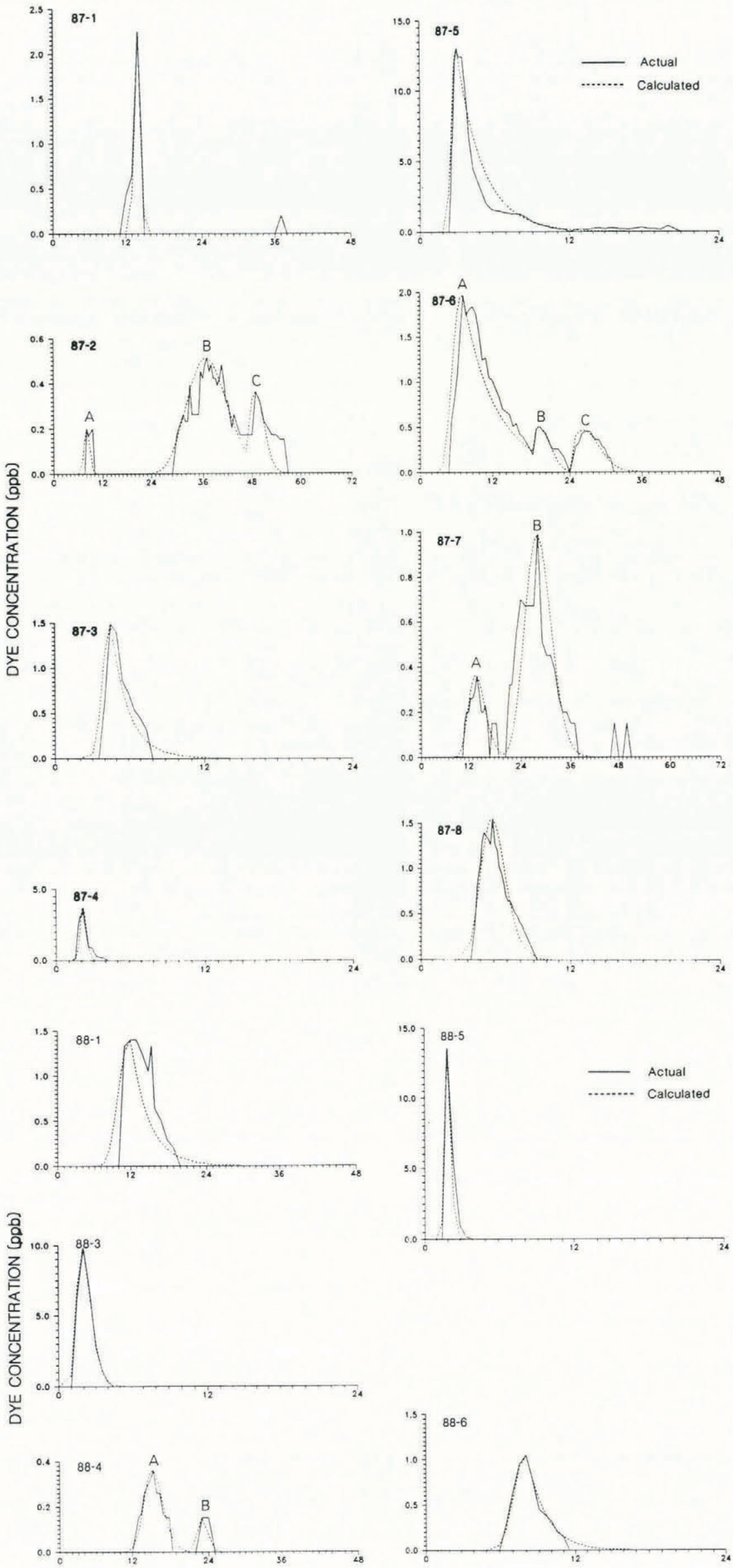

TIME SINCE INJECTION (hours)

Fig. 5. Dye concentration-time curves recorded at the gauging station for the 1987 and 1988 tests at Midtdalsbreen. Dotted curves for tests 87-1, 87-2, 87-4, 87-7, 87-8, 88-3, 88-4, 88-5, and all secondary peaks are theoretical "diffusive-dispersion" curves calculated from Equation (5). Dotted curves for tests 87-3, 87-5, 87-6a, 88-1, and 88-6 are a combination of theoretical "diffusive-dispersion" and storage-retardation" curves calculated from Equations (5) and (8).

https://doi.org/99.3189/S0022143000005608 Published online by Cambridge University Press 
appear to require a model which includes a storage and release component.

Brugman (unpublished, equation (5.16)) showed that dispersion due to storage-release mechanisms can be characterized by adding a generalized storage term to the differential equation describing dispersion (as discussed by Seaberg and others (1988, p. 221-22)). This equation takes the form:

$$
\frac{D c}{D t}=-u \frac{\mathrm{d} c}{\mathrm{~d} x}+D \frac{\mathrm{d}^{2} c}{\mathrm{~d} x^{2}}-\frac{\mathrm{d} S}{\mathrm{~d} t}
$$

where $S$ is the mean concentration of stored ("immobile") tracer and $c$ is the mean concentration of "mobile" tracer. If tracer is exchanged between immobile and mobile zones at a rate which is linearly dependent on the tracer concentration in each zone, then the temporal rate of change of tracer stored in an immobile zone is given by

$$
\frac{D S}{D t}=a c-b S
$$

where $a$ and $b$ are the rate constants governing the exchange and are in units of $\mathrm{s}^{-1}$

The dye concentration in the mobile zone (the main hydrological flow pathway through the glacier) is initially decreased as some tracer goes into storage. When $c$ drops below the concentration of tracer in the immobile zone, $S$, $D S / D t$ becomes negative and the storage zones within the glacier become net sources of dye rather than net sinks. Dye will continue to be transferred to the main flow from storage reservoirs once the peak dye concentration has passed, thus adding a tail to the dye-return curve. The falling limb of the curve for the DDSR model can be approximated by a delta-function pulse of dye arriving instantaneously at the time of peak concentration followed by an exponentially decreasing tail. Equation (6) has the following analytical solution

$c(t) \approx \frac{V_{0} a b x}{Q_{\mathrm{GS}} u} \exp \frac{-a x}{u} \exp \frac{-b(t-x)}{u}$ where $t>x / u$

(Brugman, unpublished, equations (5.26) and (5.5)).

From this equation it can be seen that the tail of the dye-return curve will be more marked for large values of the initial volume of injected dye, $V_{0}$, large travel distances, $x$, small flow velocities, $u$, and low discharges, $Q_{\mathrm{GS}}$.

To obtain the value $b$, a simple exponential regression model was fitted to the falling limb of the measured dye-return curve. Figure 6 shows the result of this model fitting for experiment 87-3. The slope coefficient of this best-fit line $\left(1.89 \times 10^{-4} \mathrm{~s}^{-1}\right)$ was used to represent the coefficient $b$ in Equation (8). The value for $a$ was obtained by solving Equation (8) by setting $c(t)$ equal to the measured peak dye concentration, $c(\max )$. Equation (8) can be expressed as follows:

$$
\ln c(\max ) \approx \ln \frac{V_{0} a b x}{Q u}-\frac{a x}{u} .
$$

$\begin{array}{lll}\text { For test } & 87-3, \quad \text { when } \quad c(\max )=1.49 \mathrm{ppb}, & V_{0}= \\ 1.46 \times 10^{-4} \mathrm{~m}^{3}, \quad u=0.086 \mathrm{~m} \mathrm{~s}^{-1}, \quad x=1400 \mathrm{~m}, & b=\end{array}$ $1.89 \times 10^{-4} \mathrm{~s}^{-1}$, and $Q_{\mathrm{GS}}=3.95 \mathrm{~m}^{3} \mathrm{~s}^{-1}$, the value of coefficient $a$ to satisfy Equation (9) is $1.5 \times 10^{-4} \mathrm{~s}^{-1}$. Values for coefficients $a$ and $b$ for those dye experiments which were not adequately described by the DD model are variable and range from $3.2 \times 10^{-5}$ to $3.2 \times 10^{-4} \mathrm{~s}^{-1}$ and from $4.5 \times 10^{-5}$ to $4.7 \times 10^{-4} \mathrm{~s}^{-1}$, respectively. The coefficient values obtained by Brugman (unpublished) for her "post-surge" experiment on Variegated Glacier lie within these ranges.

Equation (8) was used to calculate falling-limb concentration-time curves for experiments 87-3, 87-5, $87-6 \mathrm{~A}, 88-1$, and $88-6$. These theoretical curves provide a good fit to the falling limbs of the observed data (Fig. 5).

A summary of the models which best describe the observed dye-return curves is given in Table II. Most of

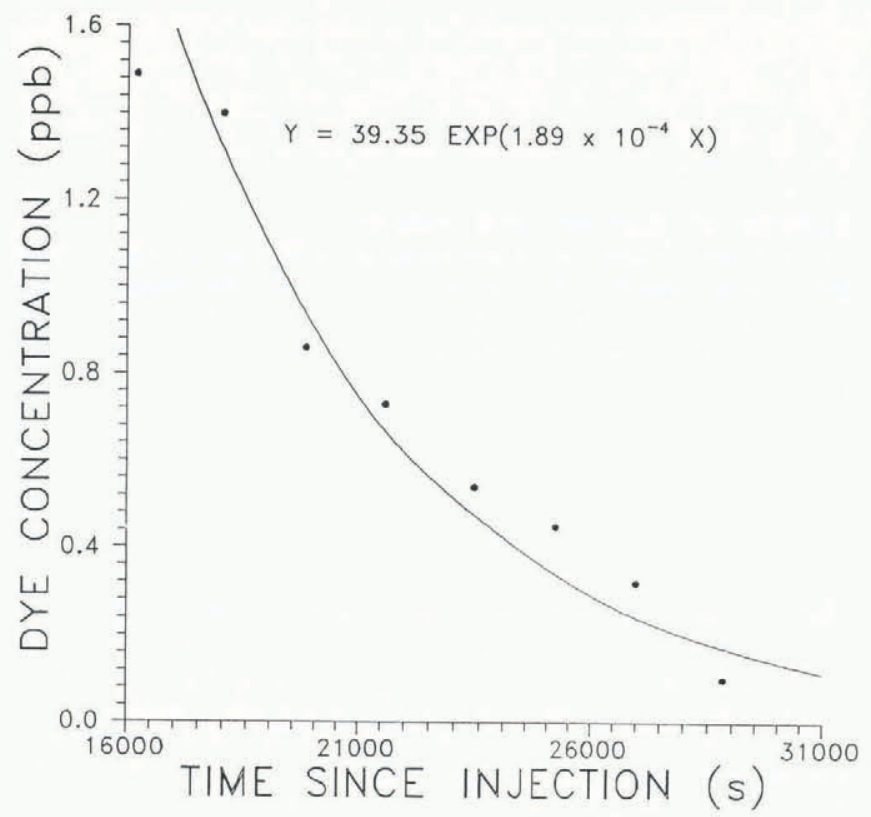

Fig. 6. Simple exponential regression model fitted to falling limb of dye-return curve for test 87-3. The slope coefficient $\left(1.89 \times 10^{-4}\right)$ is used as the b coefficient in Equation (8).

the return curves associated with individual dyeconcentration peaks can be modelled successfully with a DD model, but one of those from $\mathrm{Tl}$ and four of those from T3 require the addition of a "storage-retardation" component. Neither the DD nor the DDSR model can, however, account for the occurrence of multiple concentration peaks in experiments $87-1,87-2,87-6,87-7$, and 88-4. These appear to require the temporary immobilization of a fraction of the initial dye injection, followed by its subsequent release as what is in effect a new injection.

That most of the curves from $\mathrm{Tl}$ can be described using a DD model is consistent with the suggestion that water beneath the eastern half of the glacier is advected rapidly in a single slug through a major conduit system. Test 87-5, which produced return in $\mathrm{T} 1$ but required a DDSR model, was conducted following $4 \mathrm{~d}$ of rapidly falling discharges. Since a major conduit might not have had sufficient time to adjust to these smaller discharges by closure due to ice deformation, the drainage pathway beneath the eastern half of the glacier may then have consisted of a relatively small anabranching subglacial stream flowing across the floor of a large conduit. Such a system would contain numerous immobile storage zones in the form of areas of slow-moving or stagnant water, back eddies, or meander bends from which dye would return to the main thalweg following the passage of the dye peak.

None of the experiments which produced a return in T3 produced a single peak which can be modelled with a DD model. All those experiments which produced a single peak $(87-3,88-1,88-6)$ require a DDSR model, while the remainder produced multiple peaks $(87-1,87-2,87-6,87-7$, $88-4)$, all but one of which $(87-6 \mathrm{~A})$ fit the DD model. Those curves from T3 which require the DDSR model have higher through-flow velocities than those which are best described by the DD model (but lower through-flow velocities than experiments producing returns in $\mathrm{T} 1$ which are also described by the DD model). These patterns can be explained as follows: single peaks which require the DDSR model are probably associated with drainage via a relatively direct and unrestricted pathway in which there are storage spaces adjacent to the major channel(s); dye through-flow velocities in such a system will be relatively high, so dye concentrations in immobile zones will rapidly exceed those in the main flow pathway and the stored dye will be released as the dye peak passes to give a quasi-exponential tail to the dye-return curve (tests $87-3,87-6 \mathrm{~A}, 88-1$, and 88-6). Multiple peaks are produced when the main flow pathway is more severely restricted so that dye is advected through the glacier at slower velocities and storage spaces can be isolated from the main drainage route by falling 
discharge before concentrations in the main drainage route drop below those in the storage spaces. Dye will then be held in storage until discharge rises the next day and the storage spaces are reconnected to the main route, allowing a new dye peak to be injected into the flow.

\section{Variation of dispersion with velocity}

As the tracer is transported through the glacier, there are several mechanisms which can cause spreading of the dye peak. A large amount can be deduced about these mechanisms from analysis of the relationship between dispersion and velocity. It has been found that $D$ is approximately proportional to $u$ such that

$$
D=\propto u
$$

where $\alpha$, the constant of proportionality, is referred to as the dispersivity and has units of $\mathrm{m}$. Furthermore, it has been found that for a multiple-conduit system with internal connections $\alpha$ is generally proportional to the length of individual segments of the system such that high values of $\alpha$ indicate more distributed flow conditions (Seaberg and others, 1988; Brugman, unpublished). Dispersivity values for the Midtdalsbreen data range from 0.7 to $71.1 \mathrm{~m}$ (Table II), and are comparable to values of between 3.1 and $81.8 \mathrm{~m}$ recorded at Storglaciären.

A plot of $D$ versus $u$ for both the Midtdalsbreen and Storglaciären data (Fig. 7) reveals a general trend of increasing $d$ with increasing $u$, but the large degree of scatter about the trend shows that there is as much variation within each glacier's hydrological system as there is between them.

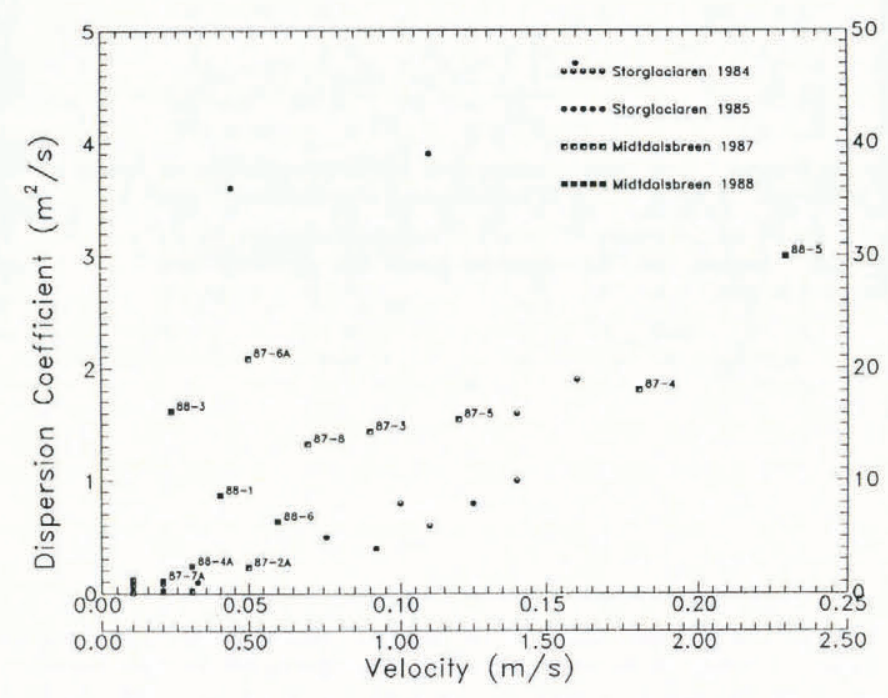

Fig. 7. Variation of dispersion coefficient, D, with velocity, $u$, for the Midtdalsbreen and Storglaciären tests. Right ordinate scale and lower abscissa scale are for test 88-3 on Midtdalsbreen.

The results of the repeated tests from site C in 1987 and site $\mathrm{H}$ in 1988, when dye travelled beneath the eastern half of the glacier and emerged in $\mathrm{Tl}$, are consistent with the model proposed by Seaberg and others (1988) for flow through Storglaciären. Dispersivity for the tests from site $\mathrm{H}$ in 1988 dropped from 71.1 to $13.1 \mathrm{~m}$ between 13 and 23 July, while discharge rose slightly from 3.17 to $3.28 \mathrm{~m}^{3} \mathrm{~s}^{-1}$. At the equivalent time of year in 1987, the dispersivity from site C, about $250 \mathrm{~m}$ down-glacier, was $12.7 \mathrm{~m}$. This suggests that in July 1988 the drainage system on the east side of the glacier became less distributed through time, and that by 23 July 1987 this system had already attained its less-distributed configuration.

The changing $\alpha$ values for the tests associated with flow to T3 on the west side of the glacier, however, suggest a different conceptual model. The dispersivity for successive tests from site $A$ in 1987 (87-1, 87-2, 87-6) increased progressively from $0.7 \mathrm{~m}$ on 11 July to $41.8 \mathrm{~m}$ on 3 August. This suggests that the hydrological network beneath this part of Midtdalsbreen became more distributed as the 1987 summer progressed. This behaviour is not, however, repeated in the tests from site $F$ in 1988. The significance of these results will be taken up in the discussion.

\section{STRUCTURE OF THE SUBGLACIAL DRAINAGE SYSTEM}

Various authors have attempted to use turbulent-flow theory to relate the water-flow velocity through glaciers to the geometry of the drainage channels and the hydraulic gradient driving the flow (Röthlisberger, 1972; Nye, 1976; Clarke, 1982; Humphrey and others, 1986; Iken and Bindschadler, 1986; Walder, 1986; Kamb, 1987; Seaberg and others, 1988; Brugman, unpublished). The approach adopted here is to assume the geometry, hydraulic gradient, and roughness characteristics of different drainage systems on the basis of models postulated by other workers in order to estimate likely through-flow velocities for each type of system. We then compare these velocities with those determined by the dye-tracing experiments in order to make inferences about the likely character of the subglacial drainage system.

\section{Straight semi-circular R-channel}

Water in $\mathrm{T} 1$ and $\mathrm{T} 3$ leaves the glacier in basal conduits incised upwards into the ice. These $\mathrm{R}$-channels are roughly semi-circular in shape and are floored with bedrock or stagnant ice. If the dye travelled from the point of injection to the glacier snout in a single straight semi-circular R-channel, its velocity would conform to the Gauckler-Manning-Strickler equation:

$$
u_{\text {act }}=R^{2 / 3} S^{1 / 2} n^{-1}
$$

where $u_{\text {act }}$ is the actual water velocity in the conduit, $S$ is the hydraulic gradient, $n$ is the Manning roughness coefficient, and $R$ is the hydraulic radius of the channel. $R$ can be found from:

$$
R=A / p
$$

where $p$ is the conduit wetted perimeter and $A$, the crosssectional area of the conduit, is given by

$$
A=Q_{\mathrm{T}} / u
$$

where $Q_{\mathrm{T}}$ is the water discharge in the tributary stream in which the dye emerged and $u$ is the water velocity determined by the dye-tracing experiment. This will provide a maximum estimate for $A$ which would, in reality, decrease up-glacier as water discharge decreases. The wetted perimeter of a filled semi-cricular conduit is

$$
p=r(\pi+2)
$$

where $r$ is the conduit radius. Equation (11) can be solved using values of $R$ from Equation (12). The hydraulic gradient can be taken as the average slope of the ice surface over the ablation zone $\left(0.12 \mathrm{~m} \mathrm{~m}^{-1}\right.$ on Midtdalsbreen $)$. Manning's $n$ for subglacial channels has been found empirically to range between 0.05 and $0.15 \mathrm{~m}^{-1 / 3} \mathrm{~s}$ (Röthlisberger, 1972; Nye, 1976; Clarke and others, 1984) and a value of $0.05 \mathrm{~m}^{-1 / 3} \mathrm{~s}$ seems appropriate to represent a straight, smooth-walled ice-bound conduit.

For test $87-1$, the mean discharge in T3 was $0.21 \mathrm{~m}^{3} \mathrm{~s}^{-1}$ and the average flow velocity through the glacier was $0.027 \mathrm{~m} \mathrm{~s}^{-1}$. If the water flowed in a straight semicircular conduit, its cross-sectional area would therefore be $7.78 \mathrm{~m}^{2}(r=2.23 \mathrm{~m})$. Equation (11), however, suggests that water flowing in a conduit of this size should achieve a velocity of $5.35 \mathrm{~m} \mathrm{~s}^{-1}$, which is $10^{2}$ times larger than that observed. Table III lists the results of the calculations for the other experiments and suggests that at no time during the summers of 1987 and 1988 could water from any injection site have been transported to the glacier terminus via a straight $\mathrm{R}$-conduit.

\section{Sinuous semi-circular $\mathbf{R}$-channel}

In reality, a conduit is unlikely to run entirely parallel to the down-glacier direction, so Equation (11) should be 


Test

Velocity
(straight
$R$-channel)

Velocity
(sinuous
$R$-channel)

Distance
through
till

$87-1$

$87-2 \mathrm{~A}$

$87-2 \mathrm{~B}$

$87-2 \mathrm{C}$

$87-3$

$87-4$

$87-5$

$87-6 \mathrm{~A}$

$87-6 \mathrm{C}$

$87-6 \mathrm{C}$

$87-7 \mathrm{~A}$

$87-7 \mathrm{~B}$

87-8

$88-1$

$88-3$

$88-4 \mathrm{~A}$

$88-4 \mathrm{~B}$

$88-5$

$88-6$

$\mathrm{m} \mathrm{s}^{-1}$
0.71
0.65
1.23
1.42
0.72
0.95
0.85
0.68
0.93
1.16
0.83
1.06
1.15

1.05
0.87
1.04
1.19
0.88
0.76

0.76
0.04

0.03

0.13

0.14

0.01

0.01

0.01

0.03

0.07

0.13

0.05

0.11

0.02

0.04

0.05

0.08

0.01

0.02

modified to account for sinuousity (length of conduit per unit down-glacier length). It is impossible to know the sinuosity of an R-channel but, on the basis of empirical results from a variety of open channels, Richards (1982, p. 182) suggested that a stream's sinuosity, $w$, can be related to the discharge-channel slope product, $\Omega$, by the formula:

$$
w=2.64 \Omega^{0.1} .
$$

Since there is independent evidence to suggest that alluvial and supraglacial streams adjust to prevailing energy conditions in similar ways (Ferguson, 1973), the conduits beneath Midtdalsbreen might also conform to Equation (15). If so, their sinuosity would vary between 1.8 and $2.4 \mathrm{~m} \mathrm{~m}^{-1}$. A value of $w=3$ thus seems to represent the maximum conceivable R-channel sinuosity. If a conduit meanders with a sinuosity of 3 , the conduit area across the water-flow direction, $A s$, is $A / w$, giving the conduit a different radius, $r$, and different values of $p$ and $R$ as determined using Equations (14) and (12). Similarly, assuming the hydraulic gradient along the sinuous channel axis, $S S$, is constant, $S s=S / w$. For experiment $87-1$, the cross-sectional area of a sinuous conduit normal to the water-flow direction would be $2.59 \mathrm{~m}^{2} \quad(r=1.28 \mathrm{~m})$ which, from Equation (11) and with $S s=0.04 \mathrm{~m} \mathrm{~m}^{-1}$, gives a water velocity in the conduit, $u_{\text {act }}$, of $2.13 \mathrm{~m} \mathrm{~s}^{-1}$. The through-flow velocity in the down-glacier direction, $u$, would be $u=u_{\text {act }} / w=0.71 \mathrm{~m} \mathrm{~s}^{-1}$. This value is still an order of magnitude larger than the observed through-flow velocity. Calculated values of $u$ in a sinuous R-channel for the other experiments are also too high for the observed velocities to be explained by uninterrupted flow through a highly sinuous R-channel, although for tests 87-4, 87-5, 88-3, and 88-5 (when dye left the glacier in $\mathrm{T} 1$ ) the observed and calculated velocities are of the same order of magnitude (Table III).

\section{Permeable sediment layer}

In their model of glacier sliding over a deformable bed, Boulton and Jones (1979) assumed that basal melt water drained by horizontal seepage through an upper permeable till layer (aquifer) resting on an impermeable substrate (aquitard). It might therefore be possible to explain the slow through-flow velocities for the dye-tracing experiments at Midtdalsbreen by assuming movement through permeable till. However, the hydraulic conductivity of till measured in situ in pro-glacial environments ranges from $10^{-12}$ to $10^{-6} \mathrm{~m} \mathrm{~s}^{-1}$ (Freeze and Cherry, 1979) with the fastest velocities of $10^{-6} \mathrm{~m} \mathrm{~s}^{-1}$ occurring through dilatant till (Boulton and others, 1974). As all the experimental dye

$\begin{array}{lc}\text { Distance } & \text { Percentage } \\ \text { through } & \text { through } \\ \text { cavities } & \text { cavities }\end{array}$

m

$\begin{array}{ll}426 & 30 \\ 195 & 14 \\ 311 & 22 \\ & \\ & \\ & \\ 619 & 41 \\ 163 & 10 \\ & \\ 163 & 10\end{array}$

through-flow velocities were of the order $10^{-1}$ or $10^{-2} \mathrm{~m} \mathrm{~s}^{-1}$, seepage through till can be rejected as the sole mechanism of water transport beneath Midtdalsbreen.

\section{Combined "aquifer-channel" system}

Shoemaker (1986) suggested a model of an "aquiferchannel" hydraulic system in which subglacial water channels are formed within a permeable substrate. At large channel spacings, drainage occurs through the aquifer and then along the channels. To test whether this two-zone model of water flow could operate beneath Midtdalsbreen, the necessary travel distances through each of the two zones were calculated by solving the following equations simultaneously:

$$
\frac{x_{\text {till }}}{u_{\text {till }}}+\frac{x_{\text {channel }}}{u_{\text {channel }}}=x / u
$$

and

$$
x_{\text {till }}+x_{\text {channel }}=x
$$

The subscripts "till" and "channel" refer to the permeable subglacial sediment and to an assumed sinuous channel system, respectively. Re-arranging Equation (16b) and substituting into Equation (16a) allows the travel distance through the channel part of the system to be calculated as follows:

$$
x_{\text {channel }}=\frac{\left\{x u_{\text {channel }}-\left[(x / u) u_{\text {till }} u_{\text {channel }}\right]\right\}}{\left(u_{\text {channel }}-u_{\text {till }}\right)} .
$$

The travel distance through the permeable substrate zone can then be calculated by re-arranging Equation (16b).

For experiment 87-1, where $x=1360 \mathrm{~m}, \quad u=$ $0.027 \mathrm{~m} \mathrm{~s}^{-1}$, and assuming $u_{\text {till }}=10^{-6} \mathrm{~m} \mathrm{~s}^{-1}$ and $u_{\text {channel }}=$ $0.71 \mathrm{~m} \mathrm{~s}^{-1}$ (the calculated down-glacier velocity through a sinuous R-channel), the necessary travel distances through till and a subglacial channel are 0.04 and $1359.96 \mathrm{~m}$, respectively. The results of calculations for the other experiments show that, in all cases, if water flows laterally through a subglacial sediment layer, it must do so for only a few centimetres before entering a main channel (Table III). These small distances indicate that water from the injection sites on the glacier surface never flowed any significant distance through a till layer. 


\section{Linked-cavity system}

Kamb (1987) has suggested that subglacial water might flow through a linked-cavity system consisting of a series of basal cavities joined hydraulically by narrow orifices. By making assumptions about the cross-sectional and planar geometry of such a system, it is possible to calculate the speed of water flow through it.

Folowing Walder (1986), it is assumed that cavities form by ice-bedrock separation in the lee of bedrock bumps and are of the "step-type" rather than the "wavetype" described by Kamb (1987). The water velocity through the wide cavity sections of the system, $u_{\text {actcav }}$, will determine the overall transit time of tracer during the dye experiments and can be found from a modification of Equation (11):

$$
u_{\text {actcav }}=R_{\text {cav }}{ }^{2 / 3} S_{\text {cav }}{ }^{1 / 2} n^{-1}
$$

where $R_{\text {cay }}$ and $S_{\text {cay }}$ are the hydraulic radius and hydraulic gradient of the cavities, respectively. To determine $R_{\text {cav }}$, it is assumed that the cavities are well developed and on the leeside of bedrock steps of height, $h$, and that they have length, $L$, in the direction parallel to ice flow and transverse to water flow such that $L=3 h$. The cavity roof is assumed to be elliptical in cross-section (Lliboutry, 1978), so that its length, $P_{\text {cav }}$, can be approximated by:

$$
P_{\text {cav }}=1.1 L
$$

(Walder, 1986, equation (4)). If $L=3 h$, the cavity's wetted perimeter, $p_{\text {cav }}$, will be:

$$
p_{\text {cav }}=h+L+P=0.3 L+L+1.1 L=2.4 L .
$$

As the cavity's cross-sectional area, $A_{\text {cav }}$, can be approximated by

$$
A_{\text {cav }}=\pi h L / 4,
$$

it follows that its hydraulic radius can be expressed as

$$
R_{\text {cav }}=\pi h / 9.6 \text {. }
$$

(N.B. This is different from the value derived by Walder (1986, equation (10)), who considered only the length of the roof, $P_{\text {cay }}$, to represent the wetted perimeter of a cavity.) If cavities are much longer in the direction parallel to ice flow such that $L=10 h$, the cavity's wetted perimeter would be $2.2 L$ and the hydraulic radius would be $\pi h / 8.8$. Changing the cavity's relative dimensions does not therefore significantly alter its hydraulic radius.

If is was assumed that all the water from a dye-injection site flows to the glacier snout in such a linked-cavity system, the cross-sectional area of the cavities could be found from Equation (13) by substituting $A$ for $A_{\text {car }}$. Then, assuming $L=3 h$, the dimensions of the cavity could be caculated by re-arranging Equation (20). If this is done for the Midtdalsbreen experiments, the cavity heights derived range from $0.76 \mathrm{~m}$ (test $87-2$ ) to $2.14 \mathrm{~m}$ (test $87-2 \mathrm{c}$ ). The dimensions are so large that it is no longer plausible to consider them as cavities. For this reason, we adopt a different approach to estimate the cavity dimensions. This approach does not necessarily assume that all the water emerging in a tributary stream travelled beneath Midtdalsbreen in a linked cavity system.

To determine appropriate values for $h$, two $12.8 \mathrm{~m}$ long profiles aligned parallel to the former direction of ice flow across exposed granite and phyllite bedrock surfaces considered to be representative of average bedrock conditions beneath Midtdalsbreen were surveyed at intervals of $0.5 \mathrm{~cm}$ using a beam and stylus profilometer (Fig. 8). The average step height for leeside cavities revealed by these profiles was $0.09 \mathrm{~m}$. This value is consistent with values found in other non-surging glaciers by measurements of the seasonal uplift of glacier surfaces (Iken and others, 1983) and by mapping of recently deglaciated bedrock surfaces (Walder and Hallet, 1979; Hallet and Anderson, 1980; Sharp and others, 1989).

The average hydraulic gradient along a cavity-orifice system is $S / w$. Following Kamb (1987) and assuming a sinuosity, $w$, of 4 , the hydraulic gradient along a cavityorifice system beneath Midtdalsbreen would therefore be $0.03 \mathrm{~m} \mathrm{~m}^{-1}$. However, the existence of orifices which throttle the flow causes most of the hydraulic potential drop to occur across them, so that the hydraulic gradient in the orifices is the average hydraulic gradient along the system multiplied by a "head gradient-concentration factor", $\wedge$ (Kamb, 1987). The hydraulic gradient in the wide-cavity sections, $S_{\text {cay }}$, which will determine the overall transit time of tracer during the dye experiments, is therefore the average gradient multiplied by the reciprocal of $\wedge$ (a "head gradient-reduction factor"), $V . S_{\text {cav }}$ in Equation (17) is therefore equal to $S V / w$. Following Kamb (1987), who used a value of 10 for the head gradient-concentration factor, a value of 0.1 is taken for $V$. Assuming $L=3 h$ and using a step height, $h$, of $0.09 \mathrm{~m}, R_{\text {cav }}$ from Equation (21) is $0.03 \mathrm{~m}$. With $w=4$ and $V=0.1, S_{\text {cay }}$ is $0.003 \mathrm{~m} \mathrm{~m}^{-1}$. With $n=0.05 \mathrm{~m}^{-1 / 3} \mathrm{~s}$, the velocity in the direction of water flow, $u_{\text {actav }}$, is $0.12 \mathrm{~m} \mathrm{~s}^{-1}$, giving a down-glacier velocity, $u_{\text {cav }}$, of $0.03 \mathrm{~m} \mathrm{~s}^{-1}$.

This is a very slow through-flow velocity but is comparable with that of $0.025 \mathrm{~m} \mathrm{~s}^{-1}$ measured during the surge of Variegated Glacier (Kamb and others, 1985; Brugman, unpublished) and with the velocities obtained from our tests $87-1,87-2,87-6,87-8,88-1,88-4$, and $88-6$. It is, however, likely to be the lowest conceivable down-glacier velocity for a linked-cavity system because it is based on a high sinuosity and a low "head gradientreduction factor". Since this calculated velocity exceeds the very low through-flow velocities suggested by test $87-7$ and the secondary peaks of tests $87-2,87-6,87-7$, and $88-4$, it appears that these velocities do not reflect average conditions beneath the glacier but, as suggested earlier, the remobilization under conditions of rising discharge of water which became trapped in storage spaces at times of low discharge.

Despite the generally good correspondence between the velocities observed in many of our experiments and that calculated for a linked-cavity system, the observed velocities show considerable variability and generally exceed the calculated value. This may be due to the choice of values for $w$ and $V$ on which $u_{\text {cav }}$ is very sensitively dependent. For example, if $V=0.1$ but $w=3, u_{\text {actcav }}$ is $0.12 \mathrm{~m} \mathrm{~s}^{-1}$, giving a down-glacier velocity of $0.04 \mathrm{~m} \mathrm{~s}^{-1}$. If $w=3$ and $V=0.3, u_{\text {cay }}$ would be $0.07 \mathrm{~m} \mathrm{~s}^{-1}$. Using plausible values of sinuosity and "head gradient-reduction factor", it is therefore possible to explain the through-flow velocities determined from dye experiments $87-1,87-2,87-6,87-8,88-1,88-4$, and $88-6$ by assuming flow through a linked-cavity system, the configuration of which was variable in both time and space. Temporary storage of water in cavities which became isolated from the active drainage network is required to account for the observed through-flow velocity of test 87-7 and the secondary and tertiary peaks in dye concentration recorded in experiments $87-2,87-6,87-7$, and 88-4.

With the exception of test $87-8$, in which flow was to $\mathrm{T} 1$, all the experiments which yielded velocities consistent with flow through a linked-cavity system were associated with flow to T3. Other experiments which produced flow to Tl yielded velocities too high to be accounted for by flow

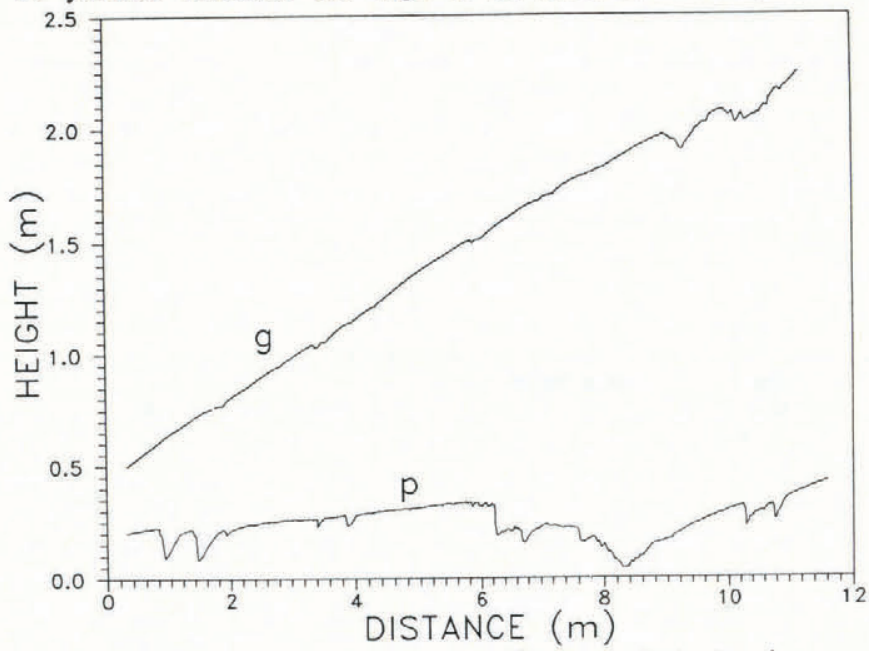

Fig. 8. Detailed topographic profiles parallel to former ice-flow direction on granite bedrock $(g)$ and phyllite bedrock $(p)$. The $x$ - and $y$-axes are plotted relative to an arbitrary datum (see Figure 1 for profile locations). 
through a linked-cavity system, but too low to be explained by flow through a sinuous R-channel. Flow through a combined "cavity-channel" system is therefore a possible explanation for the results of those experiments which produced dye return in $\mathrm{Tl}$, and it is therefore considered further in the next section.

\section{Combined "cavity-channel" system}

Several authors have suggested the possibility that a linked-cavity system might co-exist with $\mathrm{R}$-channels at the glacier bed. Lliboutry (1968, fig. 16) envisaged subglacial cavities grouped together like "a string of beads" leading into major subglacial streams. Humphrey and others (1986) concluded that during mini-surges of Variegated Glacier, "distributed flow system" (a large number of small passageways which might be blocked by constrictions) in which water flowed at less than $0.1 \mathrm{~m} \mathrm{~s}^{-1}$ existed in the upper glacier, while a small number of conduits in which water flowed at over $2 \mathrm{~m} \mathrm{~s}^{-1}$ existed beneath the lower glacier with a $1 \mathrm{~km}$ long transition zone between the two. Walder (1986) and Fowler (1987) discussed cavity-channel interaction and suggested that some R-channels could exist in cavity-dominated regions. Iken and Bindschadler (1986) concluded that it is possible for a number of moderately sized meandering conduits to be partly attached to cavities.

To provide a basis for conceptualizing a cavity-channel system beneath Midtdalsbreen, the distance travelled through a linked cavity-orifice system and through a sinuous R-channel was calculated using a modification of Equation (16c):

$$
x_{\text {channel }}=\frac{\left\{x u_{\text {channel }}-\left[(x / u) u_{\text {cav }} u_{\text {channel }}\right]\right\}}{\left(u_{\text {channel }}-u_{\text {cav }}\right)} .
$$

For experiment 87-3, where $x=1400 \mathrm{~m}, u=0.086 \mathrm{~m} \mathrm{~s}^{-1}$, and assuming $u_{\text {channel }}=0.71 \mathrm{~m} \mathrm{~s}^{-1}$ and $u_{\text {cav }}=0.03 \mathrm{~m} \mathrm{~s}^{-1}$, the travel distance through the channel part of the system from Equation (22) is $974 \mathrm{~m}$ and that through the linked-cavity section of the system is $426 \mathrm{~m}$. This indicates that for $30 \%$ of its path dye might be travelling down-glacier at $0.03 \mathrm{~m} \mathrm{~s}^{-1}$ through a system of linked cavities, while over the rest of its path it might be flowing in a large sinuous $\mathrm{R}$-channel and travelling at $0.71 \mathrm{~m} \mathrm{~s}^{-1}$. The results for all the experiments which cannot be explained by flow solely through a linked-cavity system indicate that water flowing beneath the eastern half of Midtdalsbreen or from site B close to the western margin (test 87-3) might spend between 10 and $41 \%$ of its overall travel distance moving through linked cavities (Table III).

Part of the distance ascribed to flow through linked cavities may be the distance travelled from the glacier surface through englacial conduits to the glacier bed (Hooke and others, 1988). Assuming that the englacial water-flow pattern is primarily controlled by the distribution of ice pressure, the angle of conduit descent from the glacier surface will be perpendicular to the angle, $\delta$, made by lines of equal hydraulic potential with the glacier surface. This angle is given by

$$
\delta=\tan ^{-1}\left[\rho_{\mathrm{i}}|\tan \theta| /\left(\rho_{\mathrm{w}}-\rho_{\mathrm{i}}\right)\right]
$$

where $\rho_{\mathrm{i}}$ and $\rho_{\mathrm{w}}$ are the densities of ice and water, respectively, and $\theta$ is the glacier-surface slope (Shreve, 1972). At Midtdalsbreen, where $\theta=8^{\circ}$, equipotentials will dip up-glacier at an average angle of $58^{\circ}$ and the englacial passageways will dip down-glacier at an angle of $32^{\circ}$. Assuming that the ice thickness at the dye-injection sites is $200 \mathrm{~m}$, englacial conduits will reach the glacier bed $320 \mathrm{~m}$ down-glacier of the injection sites. Therefore, tracer injected into the glacier in the dye experiments might travel up to $23 \%$ of the total transport distance through englacial passageways. If water flows through englacial passageways at down-glacier speeds as low as $0.03 \mathrm{~m} \mathrm{~s}^{-1}$ (i.e. the slowest speed at which it might travel through a linked-cavity system), then the results for dye tests $87-4,87-5,88-3$, and $88-5$ can be explained in terms of flow through englacial and subglacial conduits without recourse to a subglacial linked-cavity network. The results for tests $87-3$ and 87-8 require that at some stage, in its passage to the glacier snout, dye must have travelled through a system of linked cavities.

\section{CONCLUSIONS}

\section{Summary of results}

The dye-tracing experiments provide insight into the manner in which water flows at the bed of Midtdalsbreen. The discharge of water beneath the western side of the glacier is always about $20 \%$ of that flowing beneath the eastern side, and the pattern of water movement and inferred geometry of the subglacial passageways in the different parts of the glacier are also distinct. On the eastern side, where discharges were between 1.57 and $3.31 \mathrm{~m} \mathrm{~s}^{3} \mathrm{~s}^{-1}$ during the two melt seasons, the average through-flow velocities were between 0.070 and $0.228 \mathrm{~m} \mathrm{~s}^{-1}$. In this area, dye appears to have passed through a system of englacial passageways from injection sites $\mathrm{C}$ and $\mathrm{H}$ into a major sinuous $\mathrm{R}$-channel. From site $\mathrm{E}$, dye also passed through a linked-cavity system before entering the $\mathrm{R}$-channel. Flow through this drainage network was characterized by dispersivity values of between 10.0 and $71.1 \mathrm{~m}$, which tended to decrease through the melt season. This behaviour suggests a braided system of subglacial channels which tends towards a single channel as the summer progresses. These channels adjust to increased discharge by increasing the hydraulic gradient driving the flow and becoming less sinuous. Patterns of dye return in this system can generally be described by a "diffusivedispersion" model and they show little evidence of storage and subsequent release of dye.

The drainage network on the western side of Midtdalsbreen, where discharges were between 0.21 and $0.91 \mathrm{~m}^{3} \mathrm{~s}^{-1}$, was apparently not dominated by a major R-channel, although test 87-3 suggests that such a channel may have existed close to the western edge of the glacier. Average through-flow velocities were between 0.010 and $0.086 \mathrm{~m} \mathrm{~s}^{-1}$ and, except for test $87-3$, suggest that after flowing through englacial conduits, dye travelled its remaining subglacial travel distance through a system of linked cavities before leaving the glacier portal. This system is unable to adjust to increases in discharge solely by increasing the water velocity through the cavities. This is to be expected because most of the change in hydraulic gradient would take place across the orifices which throttle the flow of water through the system. The hydraulic gradient, and thus the through-flow velocity through a given cavity, would therefore remain relatively constant during changes in discharge. The system must therefore adjust to increases in discharge by increasing its crosssectional area. This might occur by cavity and orifice enlargement due to roof melting and/or increased glacier sliding across the bed, by increasing the number of active cavities and distributing flow more widely across the glacier bed, or by a combination of these two processes. The increase in dispersivity from 0.7 to $41.8 \mathrm{~m}$ recorded in experiments from dye-injection site $A$ during the summer of 1987 tends to suggest the second of these two mechanisms, though results from the 1988 tests, carrried out at higher discharges, are more consistent with the enlargement of individual cavities and orifices. It may be that the dominant process of adjustment varies depending upon the degree of excess capacity within the system and the rate at which discharge increases.

Half of the observed patterns of dye return in T3 are best described by a combined "diffusive-dispersion" and "storage-retardation" model, which suggests that some of the dye may pass into intermediate storage before being returned to the main flow path. If this storage occurs in cavities only weakly connected to the main drainage system, then periodic closure of these connections at times of low discharge followed by re-opening at times of higher discharge can explain the secondary peaks in dye concentration recorded in some experiments. Since these secondary peaks can be described by a "diffusivedispersion" model, it seems that the dye cloud is effectively immobilized and able to retain its integrity between successive dye-release events. It thus appears that certain parts of the linked-cavity network are only active at times of relatively high discharge, but that they may contain stored water when inactive. 
The evolution of the subglacial drainage system of Midtdalsbreen

During the winter, we have observed that the discharge of water from Midtdalsbreen drops to zero, so it is likely that the drainage network which developed during the previous summer will tend to close down in response to ice deformation. At the onset of the ablation season, the discharge of water through the glacier will be small and there will be limited interconnection between subglacial cavities at different locations on the glacier bed. As the season progresses, however, the discharge and water pressure in individual cavity-orifice pathways will increase. Cavity growth will occur as water pressure exceeds the loca ice-contact pressure, and this may open up new orifices and connections to new cavities. Water will pass along a growing number of pathways, producing a more distributed drainage system. If discharges through the glacier remain low, this linked cavity-orifice system will be stable and able to adjust to small increases in discharge and water pressure by a combination of limited orifice/cavity roof melt-back and enlargement by more rapid sliding. The drainage system beneath the western half of Midtdalsbreen does not appear to have developed beyond this stage during the summers of 1987 or 1988.

If the linked-cavity system is subjected to sustained high discharges and water pressures, however, viscous heating may cause unstable orifice growth so that the linked-cavity system evolves into a multiple-tunnel system (Kamb, 1987). The water pressure-discharge relationship in such a system renders it unstable and liable to evolve towards a single-tunnel system (Röthlisberger, 1972). The drainage system beneath the eastern side of Midtdalsbreen appears to have passed through this sequence of events in the summers of both 1987 and 1988. This is attributable to the higher discharges experienced in this part of the glacier, which are in turn probably linked to the effects of largescale bed topography which must direct water from up-glacier to this side of the glacier. The cavity-orifice system becomes unstable when enlargement of orifices by roof melting becomes so great that the water pressure within them begins to fall, allowing them to capture water from other, smaller, passageways in which water is at a higher pressure. This results initially in a multiple (braided) tunnel system which then develops into a single conduit as individual anabranches become dominant and capture water. Beneath the eastern side of Midtdalsbreen, the multipletunnel system seems to develop by early July, and a single tunnel is present by the end of July.

It appears that a stable cavity-orifice system and a major R-channel system co-exist at different parts of the bed of Midtdalsbreen. Whether or not a tunnel develops from a series of linked cavities during a particular melt season appears to depend primarily on whether or not a threshold discharge is crossed. The crossing point of the velocity-discharge relationships to $\mathrm{T} 1$ and $\mathrm{T} 3$ (Fig. 4) suggests that at Midtdalsbreen this threshold discharge may be approximately $1 \mathrm{~m}^{3} \mathrm{~s}^{-1}$, a discharge which was crossed beneath the eastern side of the glacier by mid-July of both 1987 and 1988. This threshold discharge may correspond to the crossing point of the water pressure-discharge relationships for tunnel and linked-cavity systems. At lower discharges, tunnels are unable to develop because they have a higher steady-state water pressure than cavities and therefore lose water to them. The resultant reduction in tunnel discharge causes an increase in water pressure and further water loss until the tunnel disappears. At higher discharges, cavities have a higher steady-state water pressure than tunnels and therefore drain towards them. Loss of water from cavities results in a reduction of water pressure which allows cavities to survive.

Since at a time of rising discharge a change from a linked-cavity system to a single conduit-dominated system might result in a significant reduction in the subglacial water pressure (Kamb, 1987; fig. 12), it is likely that this change in drainge-system structure would be accompanied by a significant change in the sliding behaviour of the glacier. This would be particularly true if the steady-state water pressure for the tunnel system were sufficiently low to result in water flow at atmospheric pressure over relatively large areas of the glacier. This possibility will be the subject of another paper.

\section{ACKNOWLEDGEMENTS}

I.C.W. acknowledges receipt of a research studentship from the U.K. Natural Environment Research Council. Field work was supported by Earthwatch, the Nuffield Foundation, University of Cambridge Department of Geography, Emmanuel College, the Worts Travelling Scholars Fund, and the Scandinavian Studies Fund. We should like to thank the many University of Cambridge students and Earthwatch volunteers who assisted with data collection, and particularly J.C. Gemmell for his help in organizing the 1987 field work. Thanks are also due to W. Theakstone and the Department of Geography, University of Manchester, for the loan of the fluorometer, to the Universities of Oslo and Bergen for provision of facilities at their Finse field station (Superintendent E. Leslie), to Norwegian State Railways for granting us road access to Finse, and to the staff of the Finsehytte for allowing us occasional escape from our field camp. We are grateful to J.-L. Tison for his critical comments on an earlier draft of this paper.

\section{REFERENCES}

Behrens, H., H. Bergmann, H. Moser, W. Ambach, and O. Jochum. 1975. On the water channels of the internal drainage system of the Hintereisferner, Ötztal Alps, Austria. J. Glaciol., 14(72), 375-382.

Bindschadler, R. 1983. The importance of pressurized subglacial water in separation and sliding at the glacier bed. J. Glaciol., 29(101), 3-19.

Boulton, G.S. and R.C.A. Hindmarsh. 1987. Sediment deformation beneath glaciers: rheology and geological consequences. J. Geophys. Res., 92(B9), 9059-9082.

Boulton, G.S. and A.S. Jones. 1979. Stability of temperate ice caps and ice sheets resting on beds of deformable sediment. J. Glaciol., 24(90), 29-43.

Boulton, G.S., D.L. Dent, and E.M. Morris. 1974. Subglacial shearing and crushing and the role of water pressures in tills from south-east Iceland. Geogr. Ann., 56A(3-4), 135- 145 .

Brugman, M.M. Unpublished. Water flow at the base of a surging glacier. (Ph.D. thesis, California Institute of Technology, 1986.)

Burkimsher, M. 1983. Investigations of glacier hydrological systems using dye tracer techniques: observations at Pasterzengletscher, Austria. J. Glaciol., 29(103), 403-416.

Clarke, G.K.C. 1982. Glacier outburst floods from "Hazard Lake", Yukon Territory, and the problem of flood magnitude prediction. J. Glaciol., 28(98), 3-21.

Clarke, G.K.C., W.H. Mathews, and R.T. Pack. 1984. Outburst floods from glacial Lake Missoula. Quat. Res., 22(3), 289-299.

Collins, D.N. 1982. Flow-routing of meltwater in an alpine glacier as indicated by dye tracer tests. Beitr. Geol. Schweiz, Hydrol., 28(II), 523-534.

Ferguson, R.I. 1973. Sinuosity of supra-glacial streams. Geol. Soc. Am. Bull., 84(1), 251-255.

Fowler, A.C. 1987. A theory of glacier surges. J. Geophys. Res., 92(B9), 9111-9120.

Freeze, R.A. and J.A. Cherry. 1979. Groundwater. New York, Prentice Hall.

Hallet, B. and R.S. Anderson. 1980. Detailed glacial geomorphology of a proglacial bedrock area at Castleguard Glacier, Alberta, Canada. Z. Gletscherkd. Glazialgeol., 16(2), 171-184.

Hooke, R.LeB., S.B. Miller, and J. Kohler. 1988. Character of the englacial and subglacial drainage system in the upper part of the ablation area of Storglaciären, Sweden. J. Glaciol., 34(117), 228-231.

Humphrey, N., C. Raymond, and W. Harrison. 1986. Discharges of turbid water during mini-surges of Variegated Glacier, Alaska, U.S.A. J. Glaciol., 32(111), 195-207.

Iken, A. 1978. Variations of surface velocities of some Alpine glaciers measured at intervals of a few hours. Comparison with Arctic glaciers. Z. Gletscherkd. Glazialgeol., 13(1/2), 1977, 23-35.

Iken, A. 1981. The effect of the subglacial water pressure on the sliding velocity of a glacier in an idealized numerical model. J. Glaciol., 27(97), 407-421. 
Iken, A. and R.A. Bindschadler. 1986. Combined measurements of subglacial water pressure and surface velocity of the Findelengletscher, Switzerland: conclusions about drainage system and sliding mechanism. J. Glaciol. 32(110), 101-119.

Iken, A., H. Röthlisberger, A. Flotron, and W. Haeberli. 1983. The uplift of Unteraargletscher at the beginning of the melt season - a consequence of water storage at the bed? J. Glaciol., 29(101), 28-47.

$\mathrm{Kamb}$, B. 1987. Glacier surge mechanism based on linked cavity configuration of the basal water conduit system. $J$. Geophys. Res., 92(B9), 9083-9100.

Kamb, B., and 7 others. 1985. Glacier surge mechanism: 1982-1983 surge of Variegated Glacier, Alaska. Science, 227(4686), 469-479.

Kilpatrick, F.A., W.W. Sayre, and E.V. Richardson. 1967. Discussion - flow measurements with fluorescent tracers. Am. Soc. Civ. Eng. J. Hydraul. Div., 93(HY4), 298-308.

Krimmel, R.M., W.V. Tangborn, and M.F. Meier. 1973. Water flow through a temperate glacier. International Association of Hydrological Sciences Publication 107 (Symposium at Banff 1972 - Role of Snow and Ice in Hydrology), 401-416.

Lang, H., C. Leibundgut, and E. Festel. 1981. Results from tracer experiments on the water flow through the Aletschgletscher. Z. Gletscherkd. Glazialgeol., 15(2), 209-218.

Lliboutry, L. 1968. General theory of subglacial cavitation and sliding of temperate glaciers. J. Glaciol., 7(49), 21-58.

Lliboutry, L. 1978. Glissement d'un glacier sur un plan parsemé d'obstacles hémisphériques. Ann. Géophys., 34(2), 147-162.

Nye, J.F. 1976. Water flow in glaciers: jökulhlaups, tunnels and veins. J. Glaciol., 17(76), 181-207.

Raymond, C.F. and W.D. Harrison. 1988. Evolution of Variegated Glacier, Alaska, U.S.A., prior to its surge. $J$. Glaciol., 34(117), 154-169.

Richards, K.S. 1982. Rivers, form and process in alluvial channels. New York, Methuen.

Röthlisberger, H. 1972. Water in intra- and subglacial channels. J. Glaciol., 11(62), 177-203.

Seaberg, S.Z., J.Z. Seaberg, R.LeB. Hooke, and D.W. Wiberg. 1988. Character of the englacial and subglacial drainage system in the lower part of the ablation area of Storglaciären, Sweden, as revealed by dye-trace studies. J. Glaciol., 34(117), 217-227.

Sharp, M., J.C. Gemmell, and J.-L. Tison. 1989. Structure and stability of the former subglacial drainage system of the Glacier de Tsanfleuron, Switzerland. Earth Surface Processes and Landforms, 14(2), 119-134.

Shoemaker, E.M. 1986. Subglacial hydrology for an ice sheet resting on a deformable aquifer. J. Glaciol., 32(110), 20-30.

Shreve, R.L. 1972. Movement of water in glaciers. J. Glaciol., 11(62), 205-214.

Smart, P.L. and I.M.S. Laidlaw. 1977. An evaluation of some fluorescent dyes for water tracing. Water Resour. Res., 13(1), 15-33.

Spring, U. and K. Hutter. 1981. Numerical studies of jökulhlaups. Cold Reg. Sci. Technol., 4(3), 227-244.

Stenborg, T. 1969. Studies of the internal drainage of glaciers. Geogr. Ann., 51A(1-2), 13-41.

Theakstone, W.H. and N.T. Knudsen. 1981. Dye tracer tests of water movement at the glacier Austre Okstindbreen, Norway. Nor. Geogr. Tidsskr., 35(1), 21-28.

Vivian, R. 1980. The nature of the ice-rock interface: the results of investigation on $20000 \mathrm{~m}^{2}$ of the rock bed of temperate glaciers. J. Glaciol., 25(92), 267-277.

Walder, J.S. 1986. Hydraulics of subglacial cavities. $J$. Glaciol., 32(112), 439-445.

Walder, J.S. and B. Hallet. 1979. Geometry of former subglacial water channels and cavities. J. Glaciol., 23(89), $335-346$.

Weertman, J. 1972. General theory of water flow at the base of a glacier or ice sheet. Rev. Geophys. Space Phys., 10(1), 287-333. 